\title{
A duras e pesadas penas: imprensa, identidade e nacionalidade no Brasil imperial ${ }^{1}$
}

\author{
Daniel Afonso da Silva \\ [...] a liberdade de Imprensa é um dos mais firmes \\ sustentáculos dos Governos Constitucionais. \\ João Severiano Maciel da Costa \\ [...] só governos novos, governos pouco afeitos à marcha constitucional \\ é que se temem dos abusos da liberdade de imprensa. \\ José Paula e Souza \\ Nada se há poupado nesta infeliz Provincia para inutilizar a Liberdade \\ da Imprensa, e, por conseguinte, a Constituição prática. \\ Antonio Pereira Rebouças
}

No dia 23 de junho de 1828, na cidade de Salvador, sob acusação de abuso da liberdade de imprensa, foi multado em $200 \$ 000$ e condenado à prisão de três meses o capitão do Corpo de Polícia, José Nunes da Silva. José Nunes, natural do Rio de Janeiro, havia incorporado como miliciano às forças de Cachoeira na época da Independência e depois foi soldado de tropas de $1^{\text {a }}$ linha e capitão de cavalaria na Bahia. Ficou muito insatisfeito com a sentença do Tribunal do Júri. Repudiou-a. No mesmo dia 23, por volta das cinco e meia da tarde, foi requerer explicações do responsável pelo Júri, o desembargador e ouvidor-geral do crime e juiz de direito Miguel Joaquim Cerqueira e Silva. Recebeu-as. Dado por convencido, indagou sobre a cadeia pública que lhe serviria de cárcere. $\mathrm{O}$ juiz de direito, incerto, pediu a Nunes acompanhá-lo até o escritório. O escritório ficava no segundo andar da casa. Antes de chegarem ao topo da escada, o sentenciado desferiu diversas punhaladas contra o dr. Miguel, que entrou em agonia. Ignácio Accioli de Cerqueira e Silva e irmã, Felisberta Joaquina de Cerqueira e Silva, perceberam barulho suspeito vindo do escritório do pai. Vento aziago. Gritos, talvez. De imediato, correram verificar. Encontraram o pai estirado no chão em estado moribundo. Entraram em desespero. Começaram a chorar. Lamuriar. Berrar, também. José Nunes, que ainda estava por ali, começou a agredi-los. Pessoas que passavam pelas adjacências notaram o alvoroço e providenciaram socorro. Percebendo a movimentação, o assassino fugiu às pressas. Mas, em poucas horas, foi capturado e encarcerado. Nos anos seguintes, foi destituído do cargo de capitão, julgado pelo crime e condenado à pena de morte. Em 1831, teve a pena comutada em degredo na Província de Santa Catarina. ${ }^{2}$

\section{$\mathrm{O}$ assassinato}

Ao longo do primeiro reinado, a imprensa foi se efetivando como o palco legítimo da luta política. Tornou-se destino das mais variadas convicções partidárias favoráveis e opostas às práticas e formas de governo. ${ }^{3}$ Para não perder hegemonia, o governo concebeu arcabouços jurídico-operacionais para regular a difusão dessas convicções. O Tribunal do Júri, no qual dr. Miguel fora juiz de direito, objetivava efetuar essa regulação. O sentenciamento do capitão José Nunes foi a primeira experiência do Tribunal na Bahia. As consequências não foram alvissareiras. $\mathrm{O}$ assassinato do dr. Miguel indicou aspectos da tensão vivida na Bahia expressos no embate das penas e abriu precedente para novos crimes de feição e razão similares. Os membros do corpo administrativo imperial ficaram apreensivos. $\mathrm{O}$ crime desmascarou o contexto baiano em que a segurança era ausente, inclusive entre aqueles que tinham por dever promovê-la. A situação exigia solução. Mas provida de cautela e perícia. As implicações do incidente do dia 23 de junho de 1828 ultrapassavam a esfera judicial e atingiam a esfera política. O que estava em 
jogo, para além do assassinato do juiz de direito, era a liberdade de trânsito das ideias. Esse foi o impasse que o homicídio de dr. Miguel explicitou.

\section{Os antecedentes}

Em meio às discussões das "Cortes Gerais, Extraordinárias e Constitucionais da Nação Portuguesa" instaladas em Lisboa, D. João VI, à frente da Corte bragantina no Rio de Janeiro, recebeu "representações de pessoas doutas e zelosas do progresso da civilização e das letras" acerca da imprensa. Elas reivindicavam urgente deliberação para censura e liberdade de imprensa. Afirmavam que a censura se "opunha à propagação da verdade" e que a liberdade incondicional "podia trazer" danos “à religião, à moral, ou à pública tranquilidade." ${ }^{4}$

No dia 2 de março de 1821, D. João decidiu sobre o assunto. Ordenou, por decreto, a suspensão da "prévia censura que pela atual Legislação se exigia para a impressão de escritos que se intent[assem] publicar", mas sob a condição de que "todo o impressor" seria "obrigado a remeter ao Diretor dos Estudos, ou quem suas vezes fize[sse], dois exemplares das provas que se tirarem de cada folha na imprensa." Ao diretor dos estudos caberia distribuir "uma delas a um dos Censores Régios, e ouvido o seu parecer [deixar] prosseguir na impressão" quando não se encontrasse "nada digno de censura, ou (...) suspender, até que [fossem feitas] as necessárias correções" no que contivesse "alguma cousa contra a religião, a moral, e os bons costumes, contra a Constituição e Pessoa do Soberano, ou contra a pública tranquilidade." Além dos impressores, os livreiros também deveriam passar pelo crivo do Diretor dos Estudos; do contrário, seriam multados de $100 \$ 000$ a $600 \$ 000 .^{5}$

Encerradas as Cortes, independente o Brasil e empossado D. Pedro Imperador, a questão foi retomada. O descompasso foi aparentemente resolvido pelo decreto de 2 de outubro de 1823 . Esse decreto estipulou que nenhum escrito "de qualquer qualidade, volume ou denominação" seria "sujeito à censura, nem antes, nem depois de impresso." "No entanto, também caracterizou abusos da liberdade de imprensa e suas respectivas penas. Definiu que seriam punidos aqueles que professassem contra a religião católica romana ou a moral cristã e os bons costumes, incitassem o povo à rebelião ou à desobediência das leis e autoridades estabelecidas, atacassem a forma de Governo Representativo Monárquico Constitucional, infamassem a Assembleia Nacional ou o chefe do Executivo e imputassem, sem provas, crimes a empregados públicos.

Em suma: o decreto restringia o conteúdo do impresso depois de impresso e definia penalidades aos considerados infratores. Com isso, a liberdade de imprensa ficou condicionada. As decorrências dessa questão foram objeto de intenso debate durante todo o primeiro reinado.

Em decreto de 22 de novembro de 1823, João Severiano Maciel da Costa, visconde de Queluz e conselheiro do Império, afirmou que "a liberdade de Imprensa [era] um dos mais firmes sustentáculos dos Governos Constitucionais, também o abuso dela os [levava] ao abismo da guerra civil e da anarquia"; por isso, a lei de 2 de outubro deveria ter "plena e inteira execução provisoriamente, até a instalação da nova Assembleia."” A essência desse argumento foi afirmada no artigo 179, $\$ 4$ da Constituição de 1824 que determinou que "todos [poderiam] comunicar os seus pensamentos, por palavras, escritos, e publicá-los pela Imprensa, sem dependência de censura; contanto que (...) [respondessem] pelos abusos, que comete[ssem] (...) nos casos, e pela forma, que a lei determina[sse]."»

Com o início das atividades da Câmara dos Deputados em 1826, foram criadas a Comissão de Legislação e Justiça Civil e Criminal e a Promotoria Fiscal dos Abusos da Liberdade de Imprensa. A Comissão foi composta por José Cezário de Miranda Ribeiro, José Carlos Pereira de Almeida Torres, Antonio da Silva Telles, José da Cruz Ferreira e Antônio Augusto da Silva. A Promotoria ficou a cargo do conselheiro João José da Veiga.

A primeira tarefa de Veiga foi avaliar a lei de 2 de outubro de 1823. Executado o trabalho, encaminhou Ofício a D. Pedro indicando imprecisōes e incompreensōes no artigo $8^{\circ}$ da lei. ${ }^{9}$ Esse artigo dispunha so- 
bre o abuso de imprensa contra a Assembleia Nacional e contra o chefe do Poder Executivo e decidia que quem "[infamasse ou injuriasse] a Assembleia Nacional, ou o chefe do Poder Executivo, [seria] condenado em três anos de degredo e 400 \$rs." Frente a essa determinação, Veiga apresentou quatro indagaçôes: ${ }^{10}$

1 - O crime era arrogado às duas câmaras ou a apenas uma?

2 - O abuso era configurado pela injúria à Assembleia ou/e aos membros dela?

3 - A injúria era crime se dirigida somente ao chefe do Poder Executivo ou ao governo e ministério também?

4 - Deputados e senadores poderiam ser indiciados por crime de abuso à liberdade de imprensa?

No dia 23 de junho de 1827, a Comissão competente dirimiu as dúvidas do conselheiro e explicou que:

1 - A Assembleia era composta por duas câmaras, portanto, ambas estavam compreendidas na disposição.

2 - A Assembleia era seus membros, entretanto, isoladamente, os seus membros não representavam a Assembleia; e, nessa condição, o dispositivo não recaía sobre senadores ou deputados solitários. Recaía sobre o coletivo: a Assembleia.

3 - O chefe do poder executivo era "inviolável e sagrado" "impecável e fonte de todo o bem" e que os agentes do poder em exercício eram "suscetíveis de erros e de crimes" e "sujeitos a severa responsabilidade, de que os não salva". Mas que, mesmo assim, não havia "fundamento em tal disparidade das pessoas". A injúria era crime se dirigida ao "chefe supremo da nação" ou/e aos seus primeiros representantes, os ministros.

4 - A publicação das falas dos deputados ou senadores na imprensa "não [poderia] ser criminosa, pois que [era] mera continuação da publicidade legítima com que foram proferidas", sendo assim, os seus autores não poderiam ser responsabilizados "pelos excessos, que tais falas contiverem". A publicação de excessos "mui longe de virem males, antes resultarão bens, que muito adiantarão a sociedade na marcha da civilização."11

Após a exposição desse parecer, a Comissão propôs aos deputados a incorporação de três novos artigos à lei de 2 de outubro de 1823, os quais determinariam que:

1 - O abuso de liberdade de imprensa seria configurado se a injúria fosse a quaisquer das duas câmaras da Assembleia, assim como se à totalidade ou maioria de seus membros.

2 - O chefe do Poder Executivo estava acima dos ministros. Os agravos a estes não deveriam ser diretamente imputados a ele.

3 - Não seriam incriminados aqueles que imprimissem falas de deputados ou senadores que contivessem abusos.

A Câmara deliberou e tornou decreto a proposta da Comissão. O decreto foi publicado no dia 13 de setembro de 1827 sob o título de Sobre a inteligência da lei que atualmente regula a liberdade de imprensa. ${ }^{12}$ Essas urgentes deliberação e decisão evidenciam a importância da imprensa na época ou, ao menos, dos assuntos sobre ela.

A imprensa no Brasil ganhava progressivamente condição de instrumento de discussão e elaboração política e ia se tornando o firme sustentáculo do governo constitucional imperial, como aludira o conselheiro Queluz. Entre 1827 e 1828, a liberdade de expressão ganhou expressão. Imprensa e Parlamento se tornaram loco privilegiado de crítica e luta política. Ao mesmo tempo, espaços públicos foram ganhando novos contornos e construindo novos ambientes para a intersecção e construção de sociabilidades. Vozes, ideias, gritos, gestos, cenas, opiniōes se afiguraram decisivos nas tramas da política e do poder. Isso motivava angústia, medo e receio de indivíduos postos a nu e à prova pela opinião pública; caso de $\mathrm{D}$. Pedro.

\section{As vozes na Bahia}

Desde a Independência, o governo de D. Pedro era achacado pela opinião pública na Bahia. Em meados de 1827, surgiram "rumores de que (...) um partido, se dispunha a aclamar S. M. o Imperador, Absoluto." ${ }^{13}$ Essa "injúria” expressava "posição perigosa” contra D. Pedro, seus aliados e governos. Para que o clima conspiratório não se instalasse de forma definitiva, D. Pedro nomeou José Egydio Gordi- 
lho de Barbuda para a presidência da Província. ${ }^{14}$ No dia 22 de outubro de 1827, o presidente Gordilho enviou sua primeira correspondência ao Imperador. A situação das vozes ameaçadoras foi o primeiro assunto abordado. Gordilho relatou que, com sua chegada à Bahia,

cessaram as descomposturas nos periódicos, que já não respeitavam ninguém e com especificidade incultavam diariamente os Ouvidores do Cível, e Crime (...) os espíritos achavam-se em perfeita desarmonia, e tudo eram partidos, que mutuamente se caluniaram. ${ }^{15}$

No plano específico, Gordilho comunicou que o "republicanismo" deixara de merecer o seu cuidado "desde o momento em que [pôs] um pé fora do escaler". E arrematou a questão sugerindo a D. Pedro "viver sem receio", porque, na Bahia, ele, Gordilho, conhecia a todos e todos o conheciam.

O objetivo da mensagem foi, claramente, para tranquilizar D. Pedro. Tão somente isso explica as ilusões que projetava.

Uma das primeiras medidas presidenciais de Gordilho foi a instauração do Tribunal do Júri para "tomar conhecimento dos abusos de liberdade de imprensa". Esse Tribunal, previsto na lei de 2 de outubro de 1823, deveria ser composto de sessenta juízes de fato - "homens bons", eleitos, da mesma forma que os deputados, ao início de cada legislatura. Além dos juízes de fato, deveria haver um juiz de direito para presidi-lo. ${ }^{16}$ Foi designado para esse cargo o desembargador e ouvidor-geral do crime Miguel Joaquim Cerqueira e Silva. O primeiro julgamento do Tribunal redundou em seu assassinato. D. Pedro tomou conhecimento do crime e ficou estarrecido. $\mathrm{O}$ incômodo se ampliou com a percepção de que a tensão promovida pela luta das penas que tomara o Rio de Janeiro tomara a Bahia e tomava o Brasil.

\section{$\mathrm{Na}$ trilha de soluções}

Na sessão de abertura da segunda legislatura da Câmara, no dia 3 de maio de 1830, em sua Fala do Trono, D. Pedro advertiu que, por ser "vigilante e empenhado em manter a boa ordem", era de seu "mais rigoroso dever" lembrar aos deputados "a necessidade de reprimir por meios legais o abuso que continua[va] a fazer-se da liberdade de imprensa em todo o Império"; pois, os abusos prenunciavam "grandes males" e cabia à Assembleia gerar mecanismos para evitá-los. ${ }^{17}$ Os deputados firmaram compromisso de produzir soluçóes. A reunião para discutir o assunto ocorreu no dia 10 de maio. A sessão teve início pelas dez da manhã sob presidência do deputado Costa Carvalho e presença de sessenta e nove deputados. O secretário Marcellino de Brito conduziu os trabalhos: leu ofícios pendentes e apresentou a ordem do dia. Como sempre, "empenhada na manutenção da boa ordem e felicidade do Império". ${ }^{18}$

O primeiro a fazer uso da palavra foi o deputado Xavier de Carvalho. Ele advertiu que os abusos de liberdade de imprensa eram recorrentes não pela ausência de lei que os reprimisse, mas pela sua não execução ou execução parcial. O deputado Custódio Dias foi mais longe ao observar que os abusos eram provenientes duma facção "republicana", "que se julgou autorizada ou talvez apoiada pelo governo a atacar não só os membros do governo, mas a mesma forma da constituição jurada”, pregando a adoção do absolutismo para "eclipsar o mesmo sol da corte, de cujo influxo ousavam temerariamente ostentar-se vivificados".

O deputado Carneiro Cunha refutou o deputado Custódio Dias e reforçou o argumento do deputado Xavier de Carvalho. Arguiu que era inútil uma lei que não dispusesse de devida execução, pois "todos os abusos provêm da falta de execução da lei, porque se assim não fosse, estariam já sentenciados, e tudo estava acabado".

A discussão foi ampliada com a intervenção do deputado Paula e Souza, que sugeriu a distinção entre abuso contra o governo e contra particulares. Por um lado, asseverou que abusos contra o governo "não fazem mal"; pois, "só governos novos, governos pouco afeitos à marcha constitucional é que se temem dos abusos da liberdade de imprensa" e, no fundo, "tais abusos [eram] corrigidos pela mesma imprensa e desafiando o espírito da Constituição, [punham] o povo mais habilitado para conhecer o andamento dos negócios públicos". Do contrário, o resultado seria o mau governo. Por outro lado, observou que abuso contra particulares era da maior gravidade, pois, atingir particulares era infringir na moral pú- 
blica e isso poderia alimentar o espírito de imoralidade que, por sua vez, era "a origem da escravidão e do despotismo". A correção dessas distorções adviria "menos pela lei que pela marcha da nossa Constituição, a consolidação de nosso sistema". Para tanto, era preciso acautelar o "abuso da imprensa" e o "abuso contra a liberdade dela”. Para resolver essas distorções, o deputado Paula e Souza reivindicava a imprescindibilidade de reformas. Entretanto, admitia que "todas as reformas [seriam] nulas se não [fossem] religiosamente observadas".

O deputado Xavier de Carvalho pediu novamente a palavra para reforçar seu argumento e polemizar com Paula e Souza. Disse que "desgraçadamente os abusos de liberdade de imprensa” eram provenientes da "falta de execução da lei" e não da sua falta ou imprecisão. Nesse quesito, o deputado Ribeiro de Andrada se contrapôs ao deputado Xavier de Carvalho de forma peremptória. Observou que a natureza da lei que reprimia os abusos da liberdade de imprensa era viciosa e viciada, uma confusão de ideias; pois, além de sua execução ser uma "desgraça", ela não reprimia os abusos.

O deputado baiano Lino Coutinho reforçou a proposição do deputado Ribeiro de Andrada dizendo que "não se [poderia] duvidar como já o ilustre deputado [dissera] que a lei (...) sobre a liberdade de imprensa é imperfeitíssima". E disse mais. Afirmou que o governo alimentava abusos da liberdade de imprensa porque o que mais via eram "periódicos liberais, tratar com moderação e (...) esses infames periódicos patrocinados pelo governo vomitarem infâmias contra os costumes e contra tudo que há de mais sagrado no mundo" e se as coisas continuassem daquela forma "era melhor que o governo se calasse, porque quem tem tantos crimes ou tantas faltas, não pode lançar em rosto abusos da liberdade da imprensa aos periódicos liberais."

De tão duro e enfático que fora o pronunciamento do deputado Lino Coutinho, o também baiano deputado Miguel Calmon, ministro dos Estrangeiros, ${ }^{19}$ saiu em defesa do governo. Afirmou que o governo não podia se calar nem ser calado e que cabia aos deputados, isso sim, boa-fé e perspicácia no tratamento das coisas do Brasil.

A partir desse momento, a discussão sobre o assunto imprensa foi desvirtuada. Os deputados se puseram a dispersões e tergiversações. O presidente da Câmara pediu ordem à Casa e levou a pauta do dia, o assunto imprensa, à votação. A pauta foi aprovada e resultou na nova lei da imprensa, tornada decreto em 20 de setembro daquele ano, cujo objetivo fundamental era revisar/reformar a lei de 2 de outubro de 1823 .

No essencial, a nova lei determinou que "todos [poderiam] comunicar os seus pensamentos, por palavras, escritos, e publicá-los pela imprensa sem dependência de censura, com tanto que [respondessem] pelos abusos que cometerem em exercício deste direito". De modo específico, conferiu maior refinamento à tipificação dos abusos. Definiu que os abusos de palavras e escritos não impressos também eram abusos da liberdade de imprensa e estabeleceu que aqueles que fossem apanhados professando palavras "em altas vozes, em públicas reuniōes, com manifesto ânimo de provocar ou injuriar" seriam incriminados e presos. Caracterizou, também, abusos a estrangeiros e à privacidade dos brasileiros. Quanto aos estrangeiros, resolveu em seu art. $2^{\circ}$, inciso $6^{\circ}$, que era crime professar "calúnias, injúrias e zombarias aos diferentes cultos estrangeiros, estabelecidos no país, com permissão e garantia da Constituição". Quanto ao resguardo da privacidade do cidadão, definiu em seu art. $2^{\circ}$, inciso $13^{\circ}$, como criminoso quem emitisse "injúrias contendo fatos da vida privada, ou expressōes afrontosas, dirigidas a deprimir a fama, ou crédito do cidadão, seja ou não empregado público" ${ }^{20}$

A determinação sobre os estrangeiros se deveu à demanda gerada pela ampliação de estrangeiros naturalizados ou que tiveram sua imigração incentivada. O dispositivo sobre a privacidade do cidadão foi fruto das dimensões que a categoria cidadão foi ganhando ao longo do primeiro reinado. Desde sua disposição nos artigos 6 e 7 da Constituição de 1824, a categoria cidadão foi se corporificando e a relação entre público e privado, ganhando outros contornos. Os espaços da casa e da rua foram se diferenciando. Foi se convencionando que na rua imperava a desordem e na casa, a ordem. O primeiro não poderia, nem deveria, contaminar o segundo, muito embora esse contágio acontecesse com frequência diante da ausência de regra reinante. ${ }^{21}$ 


\section{Coisas da Bahia}

O debate parlamentar de 10 de maio de 1830 foi decisivo para o estabelecimento das bases dessa lei de 20 de setembro. Durante o debate, a intervenção mais incisiva foi a do deputado baiano Lino Coutinho. Seu discurso não foi tão duro quanto o do deputado Ribeiro de Andrade que questionou a operacionalidade da lei que reprimia os abusos à liberdade de imprensa. Tampouco tão pedagógico como o do deputado Paula e Souza que, no fundo, evocou a maturidade ao sistema e da forma de governo vigentes. Foi acusatório. Acusava o governo de ser conivente e praticante do abuso da imprensa e da liberdade de imprensa. Como prova, lançava como pretexto a forma pela qual os jornais de feição liberal e seus editores, por serem contra o governo, eram maltratados e injustiçados. Para fins de exemplo, mencionou o jornal pernambucano Cruzeiro e o carioca Gazeta do Brasil. Embora não tenha apresentado exemplos da imprensa baiana, sua fala foi, certamente, motivada por causos e coisas da Bahia. Além do assassinato do dr. Miguel, ocorrido dois anos antes, em 1829 fora preso o redator d'O Bahiano, Bernardino Ferreira Nóbrega. Nos dois incidentes, o presidente Gordilho foi posto em suspeição. Jornalistas baianos ficaram apreensivos. Setores da população, chocados.

\section{Causos da Bahia (I): jornalistas liberais}

O capitão do Corpo de Polícia José Nunes da Silva, algoz do dr. Miguel, fora indiciado, julgado e condenado em 1828 por conta de carta sua publicada no periódico Soldado de Tarimba. A carta possuía suposta injúria ao cidadão Antonio Pereira Rebouças. Nela, afirmava-se, de maneira definitiva, que Rebouças era o "pior homem". ${ }^{22}$

Soldado de Tarimba era o jornal no qual o presidente Gordilho se autoelogiava e se defendia de acusações e desqualificações impressas. Seu oponente impresso principal era O Bahiano, editado por Bernardino Ferreira Nóbrega, suposto "testa de ferro" do "mulatinho redator" e "gazeteiro liberal" Antonio Pereira Rebouças. ${ }^{23}$ Nóbrega e Rebouças, partindo da ponderação do deputado Coutinho, eram os "maltratados e injustiçados" pelo governo; eram redatores de feição liberal.

Mas o que Lino Coutinho queria, efetivamente, dizer com liberal? Seriam os liberais exaltados ou moderados ou ambos? Seriam republicanos ou monarquistas? Difícil saber. De modo geral e de forma genérica, durante o primeiro reinado existiam três tipos de convicções, ou tendências, partidárias explicitadas em jornais país afora: os exaltados, os moderados e os restauradores.

Os primeiros eram considerados, pelos moderados, aqueles que perdiam a razão. Fugiam de ideias e atitudes razoáveis de uma racionalidade da coisa pública. Rendiam-se a paixóes e sentimentos. Eram solidários a livres, mestiços e escravos. Alimentavam ideais federalistas e, eventualmente, republicanos e defendiam cidadania, universalização dos direitos e ampliação da liberdade para pobres. Diante de tudo isso, eram rotulados de anarquistas, demagogos, farroupilhas, jurujubas, feras.

Os segundos almejavam a Constituição sem revolução. Moderação se apresentava como sinônimo de razão. Era ala composta por homens bons que prezavam a harmonia, os costumes, o bom senso, a sabedoria, a civilização, o equilíbrio entre o antigo e o novo. Eram os que, imbuídos nas "novas ideias", pretendiam aniquilar um processo revolucionário que, em verdade, não tinha havido. Queriam a regulação dos excessos. Diante do contexto, em 1821 queriam a unidade entre Brasil e Portugal; em 1822, defendiam a Independência associada ao Imperador; durante o primeiro reinado, a preocupação foi se distanciar dos absolutistas e exaltados; em 1830, mudar o ministério e manter o monarca; após 1831, destituir o monarca para evitar a anarquia. Moderação era, também, sinônimo de mobilidade.

Os últimos, conhecidos como caramurus, caveiras, mariolas, pés de chumbo, marinheiros, papeletas, marotos tinham como meta política a soberania monárquica frente à popular. Na década de 1820 , reiteraram o antigo regime negando a Independência. Após a abdicação em 1831, começaram a defender a volta de D. Pedro I, supervalorizando a supremacia monárquica e a aproximação com o tradicionalismo português. ${ }^{24}$ 
Esse conjunto de noções se tornou essencial na tessitura política daquele contexto. Tomar partido delas foi decisivo na demarcação de posiçóes. A imprensa as explicitava. Também por isso, foi transformada no espaço genuíno da luta das penas.

\section{Causos da Bahia (II): a prisão do redator d'O Bahiano ${ }^{25}$}

No início de 1829, foi posto preso no Forte do Barbalho, em Salvador, Bernardino Ferreira Nóbrega, redator d'O Bahiano. Nóbrega nascera em Salvador em 1800. Entrou para o Colégio Médico Cirúrgico em 1818. No dia 10 de julho de 1822, em meio à guerra de Independência na Bahia, foi nomeado cirurgião-mor do Batalhão de Itaparica instalado em Cachoeira. Finda a guerra, efetuou, provavelmente, a melhor reconstituição da campanha da Bahia no processo de Independência em suas Memórias históricas sobre as vitórias alcançadas pelos itaparicanos durante a campanha de Independência, publicadas em 1827 . Em 1828, fundou, na companhia de Antonio Pereira Rebouças, e se tornou redator do jornal O Bahiano. ${ }^{26}$

Em 1829, por Libelo crime de abuso de liberdade de imprensa, o cidadão Francisco das Chagas de Oliveira Castilho denunciou que "no n. 4 do periódico $O$ Bahiano" foi impresso e publicado "um discurso sedicioso, propalando desconfianças que [na] cidade [havia] um partido absolutista que [pretendia] destruir o Sistema Constitucional" e que isso excitava "o povo à rebelião, e à não obediência às autoridades." ${ }^{27}$ A denúncia foi acolhida pelo ouvidor do crime Caetano Ferraz Pinto e Nóbrega foi levado a julgamento perante o Tribunal do Júri para Crimes de Abuso à Liberdade de Imprensa.

O julgamento se processaria em duas etapas, ou melhor, duas reuniōes do Conselho de jurados. Não se sabe exatamente quando foi a primeira reunião. Sabe-se que nela foi deliberado, por maioria de votos, que Nóbrega era culpado. A segunda reunião foi marcada para o dia 14 de maio.

No dia 9 de maio, um sábado, saíram dois artigos n'O Bahiano, para problematizar a questão como um todo. O primeiro, disposto na primeira página, apresentou o caso do redator da Gazeta Parahiba$n a$, relatando que o referido redator tinha sido preso e processado por ter, também supostamente, escrito artigo injurioso ao governo, mas que fora absolvido na segunda reunião do Conselho de jurados do Tribunal do Júri em que indagou

como, então, na Bahia [haveria] de ser condenado o redator do Bahiano pela só razão de defender a Constituição e a Lei, pondo alerta e bem de olho vivo os Bahianos, contra maquinaçôes, que se tramavam contra a existência e perpetuidade do Código Sagrado das Liberdades Públicas Brasileiras?

O segundo artigo, intitulado "Liberdade de Imprensa", efetuou maiores digressões sobre o assunto. Reconheceu e afirmou a importância da liberdade de imprensa para os governos não despóticos. Acentuou que "os governos não sabem o mal que fazem em reservar para si o privilégio exclusivo de falar e de escrever os seus próprios atos." Ponderou que sem liberdade de imprensa, "todas as barreiras civis, políticas, judiciais, tornam-se ilusórias", pois num governo justo, os princípios da liberdade de imprensa "são simples e claros". E concluiu que no Brasil e na Bahia nada daquilo se processava.

Cinco dias depois, no esperado dia 14 de maio, a reunião do Conselho de jurados não ocorreu. Alegou-se ausência de quórum e apelou-se à lei para justificar que sem quórum não haveria deliberação. Na verdade, a lei de 2 de outubro de 1823 não dispunha sobre o quórum, nem estipulava a quantidade mínima de conselheiros necessária para deliberação. Determinava, em seu artigo 26, que "tomada a denúncia, passará o Juiz de Direito a eleger o primeiro Conselho de Juízes de Fato (...) fará extrair da urna por um menino nove das cédulas de que fala o artigo $21,{ }^{*}$ as quais indicarão as pessoas de que se há

\footnotetext{
* Que determina o seguinte: "Em cada legislatura serão eleitos para Juízes de Fato 60 homens bons escolhidos pelos Eleitores, da mesma forma que fizerem a eleição dos Deputados, e remetida ao Juiz de Direito uma cópia autêntica desta eleição, ele fará logo recolher a uma urna, que se há de guardar no Arquivo da Câmara da cabeça da Comarca, tantas cédulas quantos forem os eleitos, cujos nomes se escreverão nelas para se extraírem as necessárias nas ocasiōes de formar-se Conselho." Carta-Lei de 2 de outubro de 1823. In: Legislação Brasileira, ou Coleção Cronológica das Leis, Decretos, Resoluções de Consulta, Provisões, etc., etc., do Império do Brazil desde 1808 até 1831 inclusive contendo além do que se acha publicado nas
} 
de compor o dito Conselho". Os faltosos seriam multados em $20 \$$ na primeira vez; $50 \$$, na segunda e $100 \$$, na terceira. O aclaramento veio com o decreto de 12 de outubro de 1828 que decidia que para a deliberação era imprescindível a presença de, no mínimo, quarenta dos sessenta juízes do tribunal. Os ausentes deveriam apresentar justificativa. Do contrário, receberiam multa de $20 \$ 000$ a $40 \$ 000 .{ }^{28}$

Enfim, no dia 14 não houve sessão. Houve tensão, tumulto, prisão.

\section{O 14 de maio (I): Gordilho}

O presidente Gordilho relatou em minúcias o ocorrido no dia 14 de maio de 1829 a D. Pedro em carta do dia 29 de maio. Em sua missiva, dizia:

Marcando-se o dia 14 do corrente para se fazer a segunda reunião, e se dar a sentença definitiva, sendo então preconizado o triunfo do redator por esses mesmos anarquistas, compareceu na Casa da Câmara o grupo deles de envolta com a canalha capitaneada por um pardo advogado de nome Antônio Pereira Rebouças, verdadeiro autor do mesmo periódico, o qual vendo que o Conselho se não fazia por falta de juízes, como exige a lei, transtornando-se talvez outros planos que tivesse na esturrada imaginação, passou a fazer requerimentos intempestivos e dirigir expressões grosseiras ao Juiz de Direito, de maneira que deu ocasião a ser mais uma vez admoestado e depois ameaçado com prisão de cadeia, o que bastante foi para se fazer grande alarido de - fora -, e então cada qual insultou como quis ao mesmo magistrado, entretanto que a desordem se fez tão grande que acudiu um piquete da guarda principal por mandado do oficial que estava no expediente das ordens deste Governo.

Não sou exagerado na presença de Vossa Majestade Imperial quando digo que vi um sedicioso rompimento no largo da praça deste palácio, sendo sobremaneira, entre os estrondosos vivas à Constituição, insultando e maltratando aquele magistrado, pois não foi de outra sorte que no meio dos mesmos vivas se matou nesta Cidade a tiros de espingarda o Governador de Armas, Felisberto Gomes Caldeira.

Por este arrojo pode Vossa Majestade Imperial avaliar a quanto não se abalançaria semelhante gente se pudesse contar com alguma força, e quanto não será conseqüente a falta de pronto castigo, munida como ela está com as armas da imprensa.

Procedendo-se na forma da lei por um tal fato, foram presos os principais amotinadores, e entre estes o façanhoso advogado, como de tudo tenho dado parte a Vossa Majestade Imperial pela Secretaria competente. Este negócio estando todo entre o Poder Judiciário, não pode dizer a respeito de seu resultado, mas o certo é que se Vossa Majestade Imperial, que melhor que ninguém sabe do desleixo da administração da Justiça por toda parte, causa principal de semelhantes desordens, não tomar desde já sob seu paternal cuidado fazer com que a espada da lei desagrave ofensas públicas deste quilate, em vão empregará toda a Imperial solicitude para que nas províncias se goze em paz dos influxos de um governo sábio e de Constituição, obra magnânima política de Vossa Majestade Imperial. ${ }^{29}$

Essa foi a versão de Gordilho, cuja posição central era clara: aqueles que proferissem ofensas públicas através da imprensa eram "desordeiros" e "façanhosos" e precisavam ser medidos pela "espada da lei".

\section{O 14 de maio (II): do Auto}

A partir do Auto ou Translado do Auto de desobediência, insulto, motim, e resistência foi possível apreender com mais vivacidade do ocorrido. Segue, com base nele, uma possível reconstituição do ocorrido.

No dia 14 de maio, as partes interessadas se reuniram na Câmara Municipal de Salvador. O desembargador e ouvidor-geral do crime Caetano Ferraz Pinto verificou a ausência de diversos juízes de fato e decidiu pela não ocorrência da sessão. Antonio Pereira Rebouças, advogado do réu, discordou. Pôs-se a protestar. Exigir a continuação do julgamento. Ferraz Pinto foi irredutível. Disse que "a Lei não o permitia, pois que não se tinha reunido pelo menos o número de quarenta juízes, e apenas trinta e um,

melhores coleções, para mais de duas mil peças inéditas, coligidas pelo Conselheiro José Paulo de Figueirôa Nabuco Araújo. Rio de Janeiro: Typ. Imp. e Const. de J. Villeneuve e Comp., Tomo IV, 1838, p. 137. 
motivo porque ele Ministro, já tinha dado [a] sessão por finda”. Dada à relutância de Rebouças, exigiu ordem no Tribunal e solicitou que não se "interrompesse nem perturbasse mais no expediente de serviço”. A decisão já havia sido tomada. Os conselheiros ausentes seriam punidos na forma da lei. Vendo que era tudo em vão, advertiu que insistente desobediência poderia culminar em "pena de prisão". Nisso, "Rebouças e muitos outros, como de tropel afluíram" para junto da mesa dele e começaram "um verdadeiro motim, fazendo bulha com as cadeiras e gritando diretamente para ele Ministro com a maior acrimônia e gestos ameaçadores - 'preso um Cidadão - preso um Cavalheiro da Ordem Imperial do Cruzeiro'”. Encurralado, o desembargador Ferraz Pinto denunciou o procedimento dos manifestantes de "ilegal e criminoso". Ordenou que todos se retirassem. Isso não aconteceu. Daí, a guarda principal da Câmara e uma patrulha foram acionadas. Foram sem sucesso as investidas para conter "aos suplicados". Eles se exacerbavam cada vez mais. Expandiram-se em "gritarias". Aos berros, diziam que "estava invadida a Casa da Câmara, que o Conselho de Jurados estava debaixo de baionetas, e que ele Ministro era culpado de tudo e de as ter mandado vir".

Ferraz Pinto sinalizou ir à direção do oficial da guarda. Mas foi interceptado pelos "amotinados", que continuavam a gritar. Agora bradavam em coro "nós debaixo de baionetas (...) isso não havia de ficar assim". Ferraz Pinto ficou muito enfurecido e deu uma "pancada com vara no chão". Disse que, "ao contrário", eles "é que o tinham em coação". Com isso, os suplicados, supostamente intimidados, abriram caminho. Ele se dirigiu ao oficial da guarda e ponderou que "tudo ameaçava princípios de uma verdadeira sedição". "Eram poucos os soldados para medidas de mais rigor". Cautela seria indispensável. O oficial se reuniu à guarda para conferir cobertura ao ouvidor do crime que desejava sair do prédio.

Enquanto Ferraz Pinto descia as escadas, os "amotinados” gritavam às suas costas. Quando chegou à porta da rua, foi cercado novamente. Além de gritos "com vozes desesperadas", começaram a exprimir "gestos insultantes e atacantes" acompanhados de "expressões ofensivas misturadas com "Viva a Constituição, e a sua Majestade o Imperador". Em meio à zoada, ouviu-se "morram marotos e Lusitanos".

Assustado, Ferraz Pinto retornou apressado para o interior da Câmara e solicitou que alguém dos seus - Joaquim Antonio de Ataíde Seixas Júnior, Joaquim Ignácio de Albernaz, o sargento-mor José Locatili Dorea, José Antonio da Silva Serva, o advogado Manoel Vieira Rodrigues e o tenente-coronel Francisco Xavier de Barros Galvão - fosse comunicar ao presidente Gordilho o estado odioso das coisas. Em seguida, convocou o comandante da polícia e ordenou a prisão "dos cabeças do dito motim": Rebouças e aqueles "que estavam presentes em seu auxílio". Foi o que se processou. ${ }^{30}$

Não se sabe quanto tempo foi necessário para conter o tumulto, tampouco o requinte de violenta crueldade empregado no processo. Sabe-se que, enquanto isso, Nóbrega continuava, no dizer de Gordilho, "a tomar fresco no Barbalho."

\section{O 14 de maio (III): o contraponto Bahiano}

A versão do Auto substanciava a posição do presidente Gordilho. $\mathrm{O}$ contraponto veio d'O Bahiano.

No dia 30 de maio, sábado, um dia após a carta do presidente ao Imperador, O Bahiano reproduziu e comentou a transcrição do Auto. O redator d'O Bahiano, não identificado, indicou no final da transcrição que "mesmo, apesar da composição e dos torneios, e rodeios, dos efúgios, e subterfúgios - eis aí o Corpo de delito do sr. Desembargador Ferraz. Os Entendedores o julguem.”

Dos comentários essenciais, o primeiro foi referente às atitudes do sr. Rebouças descritas no Auto. Questionava O Bahiano: "O Rebouças não saiu do lugar, em que sempre esteve e costumou estar - Como afluiu de tropel?" e "Como em auxílio? Se faziam bulhas com as cadeiras era no Salão porque ao redor da mesa não há senão bancos fixos. E bulha com cadeiras, que naturalmente acontece quando muitas pessoas se levantam de repente pode classificar motim?"

Em seguida, questionou se as palavras de ordem, ou melhor, os gritos - que a Casa da Câmara, que o Conselho dos Jurados estava debaixo d'armas e baionetas e que ele Ministro era o culpado de tudo 
em ter mandado vir - "porventura seriam palavras próprias de Amotinadores e Amotinados; ou antes de Juízes de Fato?"

Por fim, refletiu sobre a prisão dos "amotinados" e reconheceu que ela foi baseada nos supostos insultos e agravos à Constituição e ao Imperador. Mas ponderou que "esses Vivas a Constituição, e ao Imperador" antes de tudo "provavam decerto que a Constituição e o amor devido ao Imperador, bem longe de desmerecerem, cresciam e recresciam."

\section{Do contraponto Bahiano à zoologia política}

Difícil saber se o sr. Rebouças saiu ou não de seu lugar de costume. Da mesma forma, é custoso, desnecessário e escusável ponderar se os bancos derredor da mesa do desembargador e ouvidor-geral do crime eram fixos ou móveis. Pouco avança precisar se a constatação de que a Câmara estava "debaixo d'armas e baionetas" adveio dos "amotinadores", dos "amotinados" ou dos juízes de fato. Discutir essas questóes pode ter sido, de alguma forma, importante para fins processuais. Mas o ponto essencial da polêmica foi o argumento que pusera preso, dentre outros, o sr. Rebouças. A discussão desse ponto começou antes da publicação do Auto do ocorrido.

No dia 19 de maio, cinco dias depois do incidente, O Bahiano no 27 questionou a constitucionalidade das prisões. Lembrou que as pessoas foram presas sem "causa ou culpa formada", pois dar "Vivas à Constituição" não era crime. Isso estava baseado na lei de 30 de agosto de 1828, que decidia sobre os casos em que se poderia proceder a prisão por crimes sem culpa formada. Segundo a lei, poderiam ser presos sem culpa formada apenas os que fossem "apanhados em flagrante delito" ou "indiciados em crimes, em que a lei impuser pena de morte natural, prisão perpétua, ou galés por toda a vida ou temporariamente." Não seriam "presos os indiciados sem ordem por escrito do Juiz competente."31

Ainda n'O Bahiano no 27 se observou que "supondo, que os que [estavam] presos por terem dado Vivas a Constituição, [tinham] cometido algum crime" a lei deveria ser cumprida; pois "os presos por darem Vivas a Constituição e por não prenderem os que com eles davam Vivas se [achavam] presos na Fortaleza do Mar reclusos em abóbadas com Sentinelas à vista, e de noite [eram] trancados nas mesmas abóbadas". E prosseguia:

Estes presos ainda não [tinham] causa, ou culpa formada, tendo-se passado 24 , 48, e mais horas; e ou se devem considerar em custódia, ou [estão] detidos contra a Constituição e a Lei. (...) [José Nunes da Silva, assassino do dr. Miguel] condenado, porém, à morte civil, tem toda a Fortaleza do Mar por sua, passeia por ela largamente. (...) [Como] dirão as Autoridades, fiscais d'estas prisões, que cumprem a Lei e Constituição? Como é que quem está em custódia, ou detido, tem pior prisão, do que quem está condenado à morte civil?

As críticas não pararam aí. Após apontar a total ilegalidade dos atos, puseram à prova o presidente Gordilho sugerindo que ele protegia aquela inconstitucionalidade e, por isso, não preenchia "os justos fins nos quais Vossa Majestade Imperial o mandou para esta Província encarregando-o de um importante Emprego!" Foi grafado com todas as letras que Gordilho precisava ser substituído. Para reforçar o argumento, a mensagem foi remetida a D. Pedro da seguinte forma:

Senhor, a Independência e a Constituição são bens muito Valiosos para os Brasileiros natos e adotivos. - A Constituição e a Independência jamais nos poderão ser arrebatadas para cairmos no colonismo e na escravidão. - Mandai-nos, Senhor, Mandai-nos Presidente Constitucional, em cuja boa fé, Sabedoria, e probidade descansemos, que acabando-se as desconfianças, ficarão sem nenhum uso para a Bahia as palavras "facciosos, anarquistas, revolucionários, republicanos", e outras similares, que costumam servir-se Empregados infiéis e desregrados para fazerem recair sobre a inocência as penas e sofrimentos, que a eles somente guardariam bem.

Foi o artigo mais contundente d'O Babiano sobre o assunto.

No dia 25 de maio, segunda-feira, foi publicada n'O Bahiano correspondência de um tal Político da Tempera Nova, que apontou o ocorrido do dia 14 como fruto da "corrupção camelina" que zombava da 
opinião pública e das leis. No entanto, garantiu que aquilo não ficaria impune. Afirmou que um dia "a poderosa verdade (...) [surgiria] brilhante d'entre as trevas com que a querem enegrecer [e] os que hoje zombam da luz Constitucional, amanhã, talvez, a procurem em seu socorro".

No dia seguinte, terça-feira, 26, apareceu na primeira página d'O Bahiano um argumento novo para a discussão. $\mathrm{O}$ artigo defendia que o ocorrido no dia 14 fora fruto de inconsequência do Tribunal do Júri, explicitando que

a reunião de Povo [era] ali certa; e este sempre respeitoso (...) até que as malsoantes expressões de Cale-se, cadeia, Enxovia, em audiência pública, a um Cidadão Deputado, que advoga a Causa do seu cliente, o fizeram romper no excesso de um fora, fora. Julgou tudo produto do excesso de raiva Camelina.

Aos partidários d'O Bahiano, Gordilho era o líder dos "camelos". Era o articulador da corrupção e da raiva "camelina". N’O Bahiano de 1o de junho, isso foi aludido de maneira enfática ao se grafar:

Afirma-se-nos, com toda a certeza, que o Excel. Presidente da Província, de acordo com o Desembargador Caetano Ferraz Pinto (porque ambos são acordes) assentaram em surpresa o Bahiano com o fundamento de que era um jornal perigoso e de que exigia o Slus (sic) Populi Suprema Lex esto.

No dia 4 de junho, quinta-feira, saiu n'O Bahiano uma correspondência com o mesmo teor de denúncia assinada pelo Vigia da Cameloada que relatou que o

Camelo está na razão de alguns juízes de Direito (ainda que poucos) porém da mesma raça, os quais bem dão a entender o quanto odeiam a essas Instituições de Jurados, Juízes de Paz, Câmaras Populares, \&c, \&c. porque lhes diminui influência, expondo-os até serem contestados em público! Que ousadia!!! Quanto não era melhor o saudoso tempo dos cabeças raspadas e capotes de camelão? À vista do que, não há remédio senão andar de azurrague.

"Camelos" era expressão corrente no Brasil para caracterizar adversários portugueses. Os baianos utilizavam esse recurso em suas missivas impressas nos jornais por terem alvo definido: o presidente Gordilho e seus aliados.

O presidente Gordilho e Francisco Chagas de Oliveira Castilho, além de tudo, eram portugueses natos, conquanto naturalizados brasileiros. Os articulistas d'O Bahiano estavam atentos a essas nuanças. Foram elementos decisivos no processo de deslegitimação das acusações que puseram preso o redator d'O Babiano e seus partidários.

O presidente Gordilho, segundo afins d'O Bahiano, era improcedente. Não fazia jus ao importante cargo conferido pelo Imperador. Castilho era traidor da causa do Brasil e só tinha visibilidade na Bahia por intermédio de Gordilho. Os aliados d'O Bahiano protestaram duramente. Constou do no 27 do jornal a seguinte afirmação:

Ele [Gordilho] acolhe[u] a Francisco das Chagas de Oliveira Castilho, que em 1822 e 1823 escreveu contra Vossa Majestade Imperial o Espreitador Lusitano, e fugiu para Portugal em Dois de Julho, regressando d'aí somente em 1827. Ele ao mesmo tempo, que Acolhe esse Inimigo de Vossa Majestade Imperial, persegue aqueles que em 1822 e 1823 a todos os Sacrifícios se expuseram para aclamar a Vossa Majestade Imperial e sustentar a Sua Aclamação com eterna glória. Ele chama de facciosos os melhores Amigos de Vossa Majestade Imperial Constitucional, porque enérgicos defendem a Constituição, que Vossa Majestade Imperial nos Outorgou, Jurou e nos Mandou Jurar. Pois, Senhor, havemos nós os Brasileiros deixar de ser fiéis aos nossos Juramentos e de defender com a Constituição o Esplendor Verdadeiro do Trono de Vossa Majestade Imperial e a felicidade da nossa (...) Pátria?

Seria difícil para D. Pedro responder a essa assertiva possuída de muita consistência e propriedade. A melhor resposta, embora D. Pedro provavelmente não tenha tido participação direta no incidente, veio com a absolvição do redator d'O Bahiano. 


\section{O elo encontrado}

A partir do assassinato do dr. Miguel, a crise política do governo de D. Pedro se tornou evidente na Bahia. Parlamentares e a sociedade civil perceberam imediatamente a fragilidade institucional reinante. A imprensa se tornou importante vetor de divulgação e publicização disso tudo. As duras críticas ao governo e as não menos duras críticas aos autores de críticas ao governo pintavam o cenário onde a opinião pública se firmava como instrumento decisivo e impreterível da luta política. O governo imperial precisou assimilar e delegar sobre isso com urgência. A propagação das ruínas do Império aumentava progressivamente por todo canto. Os abusos da imprensa e da liberdade de imprensa, também. O aparato jurídico-operacional, para contê-los, foi amadurecendo ao longo do primeiro reinado. Mas, ao menos na Bahia, galgou pouco sucesso. Os incidentes baianos de 1828 e 1829 agiram como forças centrífugas e centrípetas nesse processo. Puseram à prova a efetividade dos Tribunais do Júri para Crimes de Abusos de Liberdade de Imprensa e fortaleceram a necessidade de maior e melhor debate sobre o assunto nos órgãos deliberativos do Estado. A reconstituição desses e outros casos baianos ajuda a reforçar o reconhecimento da afirmação que sugere que a imprensa brasileira e baiana e o Estado nacional na Bahia e no Brasil foram constituídos a duras e pesadas penas.

\section{Notas}

${ }^{1}$ Agradeço a Douglas Guimarães Leite, Fábio Rocha Teixeira, Hendrik Kraay, Henrique Antonio Ré, István Jancsó, Marco Morel, Sérgio Montejunas Ramos, Silvia Carla Pereira de Brito Fonseca, Vanicleia Silva Santos e Wilson do Nascimento Barbosa pelos comentários desferidos a diferentes versões deste texto, dentre elas, a que consta de meu Histórias de Bahia, Histórias de Brasil: cinco estudos sobre a crise do primeiro reinado na Bahia (1828-1831). São Paulo, 2007. (Dissertação apresentada ao Programa de Pós-graduação em História Social do Departamento de História da Universidade de São Paulo).

${ }^{2}$ ACCIOLI, Ignácio (de Cerqueira e Silva). Memórias históricas e políticas da Babia. Anotado por Braz do Amaral. Salvador: Imprensa Oficial, v. 4, 1931, p. 238-9; Coleção Requerimentos do século XIX. (Consta do Arquivo Histórico do Exército AHEx, caixa 6221, maço 133, no 3830.) Agradeço ao capitão Corrêa e equipe pelo empenho na localização do documento e pelo conjunto de esclarecimentos sobre o Exército oitocentista.

${ }^{3}$ MOREL, Marco. As transformaçôes dos espaços públicos: imprensa, atores políticos e sociabilidades na cidade imperial (18201840). São Paulo: Hucitec, 2005; LUSTOSA, Isabel. Insultos impressos: a guerra dos jornalistas na Independência (1821-1823). São Paulo: Cia. das Letras, 2000; NEVES, Lúcia Maria Bastos das. Corcundas e constitucionais: a cultura política da Independência (1820-1822). Rio de Janeiro: Revan/Faperj, 2003; LESSA, Mônica Leite \& FONSECA, Silvia Carla Pereira de Brito (Org.). Entre a monarquia e a república: imprensa, pensamento politico e historiografia (1822-1889). Rio de Janeiro: Eduerj, 2008.

${ }^{4}$ Decreto de 2 de março de 1821 - Sobre a liberdade de imprensa. In: Coleção de Leis do Império (1808-1889). Rio de Janeiro: Imprensa Nacional, 1889, p. 25.

${ }^{5}$ Id., ibid.

${ }^{6}$ Carta-Lei de 2 de outubro de 1823. In: Legislação Brasileira, ou Coleção Cronológica das Leis, Decretos, Resoluções de Consulta, Provisóes, etc., etc., do Império do Brazil desde 1808 até 1831 inclusive contendo além do que se acha publicado nas melhores coleçôes, para mais de duas mil peças inéditas, coligidas pelo Conselheiro José Paulo de Figueirôa Nabuco Araújo. Rio de Janeiro: Typ. Imp. e Const. de J. Villeneuve e Comp., Tomo IV, 1838, p. 165.

${ }^{7}$ Decreto de 22 de novembro de 1823. In: Legislação Brasileira, op. cit., p. 165.

${ }^{8}$ Constituição Política do Império do Brasil. Rio de Janeiro: Typ. de Silva Porto e C., 1824.

${ }^{9}$ Anais do Parlamento Brasileiro - Câmara dos Senhores Deputados. Sessão de 23 de junho de 1827. Rio de Janeiro: Typ. de H. J. Pinto, 1878, p. 134-5.

${ }^{10}$ Carta-Lei de 2 de outubro de 1823, op. cit.; Ofício do conselheiro João José da Veiga. Anais do Parlamento Brasileiro Câmara dos Senhores Deputados. Sessão de 23 de junho de 1827, op. cit., p. 134-5.

${ }^{11}$ Parecer da Comissão de legislação e justiça civil e criminal. Anais do Parlamento Brasileiro - Câmara dos Senhores Deputados. Sessão de 23 de junho de 1827, op. cit., p. 135-6.

${ }^{12}$ Decreto de 13 de setembro de 1827. In: Coleção de Leis do Império do Brasil de 1827. Rio de Janeiro: Typ. Nacional, parte I, 1878, p. 40.

${ }^{13}$ Ofício do presidente interino da Bahia Manuel Ignácio da Cunha Menezes ao governo imperial. Palácio do Governo da Bahia, 26 de maio de 1827. Apud AMARAL, Braz do. História da Bahia: do Império à República. Bahia: Imprensa do Estado, 1923, p. 36. 
${ }^{14}$ José Egydio Gordilho de Barbuda é personagem controversa. Alguns intérpretes sugerem que ele nasceu em São Pedro do Rio Grande do Sul. Outros afirmam que ele nasceu em Portugal. Não localizei nenhum documento que comprove a primeira ou a segunda assertiva. No entanto, há indícios que corroboram a tese dele ser português. O principal indício, talvez, advenha da ausência de Gordilho na história do Exército brasileiro. A “memória histórica do Exército brasileiro" possui o dossiê de, praticamente, todos os oficiais - especialmente, os nascidos em território brasileiro - que assentaram praça ou prestaram serviços à causa do Brasil a partir da Independência. Gordilho não aparece no rol. Aparece o seu filho, de nome homônimo perfeito, que fez carreira expressiva no Exército brasileiro e em governos provinciais e foi tornado segundo visconde de Camamu. Outro indício que reforça a identidade portuguesa do primeiro visconde de Camamu é a recomposição da trajetória da família Gordilho confeccionada por Osvaldo Veloso Gordilho. Nesse trabalho, Osvaldo Gordilho afirma que o primeiro membro da família Gordilho, nascido no Brasil foi o segundo visconde de Camamu. Esses pressupostos não encerram o enigma acerca do Gordilho objeto deste estudo. Admitindo-o português, sua melhor reconstituição biográfica foi efetuada por Ignácio Accioli de Cerqueira e Silva. Segundo Accioli, Gordilho nasceu no Porto em agosto de 1773, filho do desembargador José Júlio Henriques Gordilho de Cabral e d. Maria Bárbara Cabral Veloso de Barbuda. Fez estudos preparatórios para o Exército e assentou praça na ilha da Madeira, onde se tornou oficial em 1808. No ano seguinte, seguiu para o Rio de Janeiro e prestou serviços ao primeiro regimento de cavalaria. Em 1817, atuou contra os revolucionários pernambucanos. Durante a guerra de Independência da Bahia, comandou tropa de segunda linha. Em seguida, recusou efetuar juramento à Junta Provisória e, em decorrência, foi preso e enviado a Lisboa. Lá jurou a causa do Brasil, retornou ao Rio de Janeiro e foi enviado novamente à Bahia em 1823. Em 1824, foi nomeado comandante das armas do governo da Bahia. Em janeiro de 1826, foi presidente de São Pedro do Rio Grande do Sul. Em outubro de 1827, foi nomeado presidente da Bahia onde foi assassinado em 1830. O conjunto dessas informaçôes consta de, especialmente, ACCIOLI, Ignácio (de Cerqueira e Silva). Memórias históricas e políticas da Bahia. Anotado por Braz do Amaral. Salvador: Imprensa Oficial, v. 4, 1931, p. 231 ss.; WILDBERGER, Arnold. Os presidentes da Provincia da Bahia, 1824-1889. Salvador: Typ. Beneditina, 1949, p. 67-79; GORDILHO, Osvaldo Veloso. Duzentos anos da família Gordilho. Trajetória da família narrada por um descendente de 1801 até o presente. Salvador: edição do autor, 1993; SILVA, Daniel Afonso da. Nem Gordilho, nem D. Pedro: paradoxo da Bahia, paradoxo do Brasil. In: Histórias de Bahia, Histórias de Brasil, op. cit.

${ }^{15}$ Correspondência de Gordilho a D. Pedro I. Salvador, 22 de outubro de 1827. In: D’ESCRAGNOLLE, Luiz Affonso. O Visconde de Camamu e o derrame de moedas falsas de cobre na Bahia. II Congresso de História da Bahia, Salvador, Revista do Instituto Geográfico e Histórico da Bahia, p. 144-6, 1952.

${ }^{16}$ Carta-Lei de 2 de outubro de 1823 , op. cit., artigos $19^{\circ}$ ao $45^{\circ}$.

${ }^{17}$ Fala do Trono de 3 de maio de 1830. Anais do Parlamento Brasileiro - Câmara dos Senhores Deputados. Sessão Imperial de Abertura. Rio de Janeiro: Typ. de H. J. Pinto, 1878, p. 63.

${ }^{18}$ Anais do Parlamento Brasileiro - Câmara dos Senhores Deputados. Sessão de 10 de maio de 1830. Rio de Janeiro: Typ. de H. J. Pinto, 1878, p. 95-7 ss.

${ }^{19}$ GALVÃO, Miguel Araújo. Relação dos cidadãos que tomaram parte no governo do Brasil no período de março de 1808 a 15 de novembro de 1889. Rio de Janeiro: Ministério da Justiça, 1969, p. 20-3.; Anais do Parlamento Brasileiro - Câmara dos Senhores Deputados. Sessão de 10 de maio de 1830, op. cit., p. 102-4.

${ }^{20}$ Lei de 20 de setembro de 1830 - Sobre o abuso da liberdade de imprensa. In: Coleção de Leis do Império do Brasil de 1830. Rio de Janeiro: Typ. Nacional, parte I, 1876, p. 35-49.

${ }^{21}$ MATTOS, Ilmar Rolhoff. O Tempo Saquarema. São Paulo: Hucitec, 1987, p. 122 ss.; DA MATTA, Roberto. Carnavais, Heróis e Malandros: para uma sociologia do dilema brasileiro. Rio de Janeiro: Guanabara, 1990.

${ }^{22}$ Representação dos juízes do tribunal do júri para assuntos de "abuso da liberdade de imprensa” ao Imperador. Salvador, 23 de junho de 1828. In: ACCIOLI, Ignácio. Memórias históricas e políticas da Bahia, op. cit., p. 239-40; O Bahiano, no 52, seção Correspondências. Salvador, 3 de julho de 1828. (Consta do acervo da FPC-CMAPBa, Série: Processos-crime, Seção de Arquivo Colonial e Provincial, documento Revolução - Bahia, Cachoeira, São Félix - (1827-1829), Conspiração contra a forma de Governo, maço 2855).

${ }^{23}$ Gordilho chamava Nóbrega de "testa de ferro" de Rebouças. A denominação "gazeteiro liberal” era atribuída a Rebouças por Cipriano Barata. O conjunto dessas informaçôes consta de Renato Berbert de CASTRO - A Tipografia Imperial e Nacional, da Bahia, op. cit., p. 83 e Cipriano BARATA - Desengano ao público ou exposição dos motivos da minha arbitrária prisão na Província da Bahia (primeira parte). Rio de Janeiro: Typ. de Lessa \& Pereira, 1831, p. 16, nota 2. (Consta do acervo do Centro de Documentação e Informação Cultural sobre a Bahia da Fundação Clemente Mariani - CEDICFCM); ver, também, CASTRO, Renato Berbert de. A Tipografia Imperial e Nacional, da Bahia (Cachoeira, 1823 - Salvador, 1831). São Paulo: Ática, 1984. p. 83.

${ }^{24}$ Ver CASTRO, Paulo Pereira de. A experiência republicana, 1831-1840. In: HOLANDA, Sérgio Buarque de (Dir.) História Geral da Civilização Brasileira. O Brasil monárquico: dispersão e unidade. Regência. Rio de Janeiro: Bertrand Brasil, $2002 . ;$ MOREL, Marco. Cipriano Barata na Sentinela da Liberdade. Salvador: Academia de Letras da Bahia, 2001, p. 264; MOREL, Marco. As transformaçôes dos espaços públicos, op. cit.; BASILE, Marcello Otávio Neri de Campos. O império em cons- 
trução: projetos de Brasil e ação política. Rio de Janeiro, 2004. (Tese apresentada ao programa de pós-graduação do Departamento de História da UFRJ.) FONSECA, Silvia Carla Pereira de Brito. A ideia de república no Império do Brasil: Rio de Janeiro e Pernambuco (1824-1834). Rio de Janeiro, 2004. (Tese apresentada ao programa de pós-graduação do Departamento de História da UFRJ.)

${ }^{25}$ Os números d'O Bahiano utilizados neste texto - exceto o 52 - constam do acervo do IEB-USP.

${ }^{26}$ Memórias históricas sobre as vitórias alcançadas pelos itaparicanos no decurso da campanha da Bahia, quando o Brasil proclamou a sua Independência. Dedicada ao ilustríssimo e excelentíssimo sr. Manoel Ignácio da Cunha e Menezes. Bahia: Typ. Imperial e Nacional, 1827. Nova edição e notas por Pirajá da Silva. Bahia, 1923. Nota 1: Biografia do Historiador da Epopeia Itaparicana. (Consta do acervo do Instituto Histórico e Geográfico Brasileiro - IHGB.)

${ }^{27}$ Libelo. Bahia: Typ. Viúva Serva e Filhos, 1829 (consta do acervo da Biblioteca Nacional - BNRJ, setor Obras Raras, PM, $3,514)$.

${ }^{28}$ Carta-Lei de 2 de outubro de 1823, op. cit. p. 137; Decreto de 12 de setembro de 1828 - Regula as sessóes dos Juízes de Fato para as causas da liberdade de imprensa. In: Coleção das Leis do Império de 1828. Rio de Janeiro: Typ. Nacional, 1878. Primeira parte. (Consta do sítio www.camara.gov.br)

${ }^{29}$ Carta de Gordilho para D. Pedro I. Salvador, 29 de maio de 1829. Apud CASTRO, Renato Berbert de. A Tipografia Imperial e Nacional, da Bahia, op. cit., p. 84-5. Grifo meu.

${ }^{30}$ Translado do Auto de desobediência, insulto, motim, e resistência, como abaixo se declara. In: O Bahiano, n. 32. Salvador, 30 de maio de 1829.

${ }^{31}$ Lei de 30 de agosto de 1828 - Declara os casos em que se pode proceder a prisão por crimes sem culpa formada. In: Coleção das Leis do Império de 1828. Rio de Janeiro: Typ. Nacional, 1878. Primeira parte, p. 29. (Consta do sítio www.camara.gov.br)

\section{Referências bibliográficas}

ACCIOLI, Ignácio (de Cerqueira e Silva). Memórias históricas e políticas da Bahia. Anotado por Braz do Amaral. Salvador: Imprensa Oficial, v. 4, 1931.

AMARAL, Braz do. História da Bahia: do Império à República. Bahia: Imprensa do Estado, 1923, p. 36.

Anais do Parlamento Brasileiro - Câmara dos Senhores Deputados. Sessão de 23 de junho de 1827. Rio de Janeiro: Typ. de H. J. Pinto, 1878.

BASILE, Marcello Otávio Neri de Campos. O império em construção: projetos de Brasil e ação política. Tese apresentada ao programa de Pós-graduação do Departamento de História da UFRJ. Rio de Janeiro, 2004.

CASTRO, Paulo Pereira de. A experiência republicana, 1831-1840. In: HOLANDA, Sérgio Buarque de (Dir.) História Geral da Civilização Brasileira. O Brasil monárquico: dispersão e unidade. Regência. Rio de Janeiro: Bertrand Brasil, 2002.

CASTRO, Renato Berbert de. A Tipografia Imperial e Nacional, da Bahia (Cachoeira, 1823 - Salvador, 1831). São Paulo: Ática, 1984.

Coleção de Leis do Império (1808-1889). Rio de Janeiro: Imprensa Nacional, 1889.

Constituição Política do Império do Brasil. Rio de Janeiro: Typ. de Silva Porto e C., 1824.

D’ESCRAGNOLLE, Luiz Affonso. O Visconde de Camamu e o derrame de moedas falsas de cobre na Bahia. II Congresso de História da Bahia, Salvador, Revista do Instituto Geográfico e Histórico da Bahia, p. 144-6, 1952.

FONSECA, Silvia Carla Pereira de Brito. A ideia de república no Império do Brasil: Rio de Janeiro e Pernambuco (1824-1834). Tese apresentada ao programa de Pós-graduação do Departamento de História da UFRJ. Rio de Janeiro, 2004.

GALVÃO, Miguel Araújo. Relação dos cidadãos que tomaram parte no governo do Brasil no período de março de 1808 a 15 de novembro de 1889. Rio de Janeiro: Ministério da Justiça, 1969.

GORDILHO, Osvaldo Veloso. Duzentos anos da família Gordilho. Trajetória da família narrada por um descendente de 1801 até o presente. Salvador: edição do autor, 1993.

LEGISLAÇÃO Brasileira, ou Coleção Cronológica das Leis, Decretos, Resoluções de Consulta, Provisões, etc., etc., do Império do Brazil desde 1808 até 1831 inclusive contendo além do que se acha publicado nas melhores coleções, para mais de duas mil peças inéditas, coligidas pelo Conselheiro José Paulo de Figueirôa Nabuco Araújo. Rio de Janeiro: Typ. Imp. e Const. de J. Villeneuve e Comp., Tomo IV, 1838. p. 165. 
LESSA, Mônica Leite \& FONSECA, Silvia Carla Pereira de Brito (Org.). Entre a monarquia e a república: imprensa, pensamento politico e historiografia (1822-1889). Rio de Janeiro: EdUERJ, 2008.

LUSTOSA, Isabel. Insultos impressos: a guerra dos jornalistas na Independência (1821-1823). São Paulo: Cia. das Letras, 2000.

MATTOS, Ilmar Rolhoff. O tempo Saquarema. São Paulo: Hucitec, 1987.

DA MATTA, Roberto. Carnavais, heróis e malandros: para uma sociologia do dilema brasileiro. Rio de Janeiro: Guanabara, 1990.

MEMÓRIAS históricas sobre as vitórias alcançadas pelos itaparicanos no decurso da campanha da Bahia, quando o Brasil proclamou a sua Independência. Dedicada ao ilustríssimo e excelentíssimo sr. Manoel Ignácio da Cunha e Menezes. Bahia: Typ. Imperial e Nacional, 1827. Nova edição e notas por Pirajá da Silva. Bahia, 1923. Nota 1: Biografia do Historiador da Epopeia Itaparicana.

MOREL, Marco. As transformaçôes dos espaços públicos: imprensa, atores políticos e sociabilidades na cidade imperial (1820-1840). São Paulo: Hucitec, 2005.

Cipriano Barata na Sentinela da Liberdade. Salvador: Academia de Letras da Bahia, 2001.

NEVES, Lúcia Maria Bastos das. Corcundas e constitucionais: a cultura política da Independência (1820-1822). Rio de Janeiro: Revan/Faperj, 2003.

SILVA, Daniel Afonso da. Histórias de Bahia, Histórias de Brasil: cinco estudos sobre a crise do primeiro reinado na Bahia (1828-1831). Dissertação apresentada ao Programa de Pós-graduação em História Social do Departamento de História da Universidade de São Paulo. São Paulo, 2007.

WILDBERGER, Arnold. Os presidentes da Provincia da Bahia, 1824-1889. Salvador: Typ. Beneditina, 1949.

\section{RESUMO}

O texto apresenta estudo sobre a construção da imprensa brasileira durante o primeiro reinado. Reflete sobre a certificação da imprensa como espaço privilegiado da luta política. Analisa a relação centrípeta e centrífuga entre Babia e Rio de Janeiro na efetivação da opiniāo pública. Interpreta discussōes parlamentares sobre liberdade e censura de expressão. Afirma a importância da imprensa na consolidação da identidade nacional brasileira.

Palavras-chave: imprensa, primeiro reinado, nacionalidade.

\section{ABSTRACT}

The text presents a study about the construction of the Brazilian press during the first reign. It turns throw the certification of the press as privileged space of the political fight. It analyzes the centripetal and centrifugal relationship between Bahia and Rio de Janeiro as result of the public opinion. It interprets parliamentary discussions on freedom and expression censorship. It affirms the importance of the press in the consolidation of the Brazilian national identity. Keywords: press, first reign, nationality. 